\title{
PENGEMBANGAN SISTEM KLASIFIKASI UKURAN PAKAIAN MENGGUNAKAN METODE BODY MEASUREMENT DAN FUZZY LOGIC BERBASIS SENSOR KINECT
}

\author{
Alexander A S Gunawan, Erwin, Widodo Budiharto \\ School of Computer Science, Bina Nusantara University, Jakarta, Indonesia \\ Email: aagung@binus.edu
}

\begin{abstract}
Abstrak
Di dalam kehidupan sehari-hari, penentuan klasifikasi ukuran pakaian biasanya dilakukan dengan mencoba-coba pakaian terlebih dahulu sehingga membutuhkan waktu yang lebih lama. Dalam makalah ini, kita ingin membangun sistem untuk mengidentifikasi ukuran tubuh manusia dengan kamera. Selanjutnya dilakukan klasifikasi ukuran pakaian secara otomatis berdasarkan ukuran tubuh tersebut. Pendekatan yang diajukan untuk memecahkan hal ini adalah dengan metode body measurement dan Fuzzy Logic dengan menggunakan Kinect sebagai sensor. Metode body measurement digunakan untuk mengukur ukuran anggota tubuh manusia berdasarkan citra yang berasal dari sensor Kinect. Fuzzy Logic digunakan untuk menentukan klasifikasi ukuran pakaian berdasarkan hasil pengukuran yang diperoleh. Sistem pengukuran dak klasifikasi ini dapat mempermudah penentuan klasifikasi ukuran pakaian yang pas. Hasil dari penelitian ini menunjukkan bahwa sistem klasifikasi yang dibangun dapat menentukan ukuran pakaian dengan False Match Rate (FMR) sekitar 2.69\%.
\end{abstract}

Kata kunci: klasifikasi ukuran pakaian, kamera, body measurement, fuzzy logic, kinect

\begin{abstract}
In our daily life, determining cloth size is usually done by trial-error beforehand and thus require a longer time.In this paper, we would like to develop system for identification of human body size by camera. Furthermore, this research want to classify the cloth size automatically based on the human body size. The approach to resolve this goal is by using body measurement method and Fuzzy Logic based on Kinect sensor. Body measurement method is used to measure the size of the human's body part based on visual data from Kinect. Fuzzy Logic is then used to classify the cloth size based on the body measurement results. Our measuring and classifying system can simplify the determination of fitting clothing size. Based on the experiment, the classifying systemcan be used to determine the cloth size with False Match Rate (FMR) about $2.69 \%$.
\end{abstract}

Keywords: cloth size classification, camera, body measurement, fuzzy logic, kinect

\section{PENDAhUluan}

\subsection{Latar Belakang Pemasalahan}

Pakaian merupakan salah satu hal yang paling dibutuhkan manusia dalam kehidupan sehari-hari. Salah satu cara untuk mendapatkan pakaian adalah dengan membelinya melalui situs 
jual-beli online. Untuk mengatasi keharusan untuk mencoba ketika membeli pakaian terutama ketika transaksi dilakukan melalui situs jual-beli online, muncul ide untuk mencoba dan mencocokkan produk pakaian yang dijual melalui bantuan perangkat lunak. Ide ini didukung dengan semakin banyaknya penggunaan sensor-sensor perekam pergerakan manusia seperti Kinect yang digunakan untuk permainan [5].

Salah satu solusi yang diajukan untuk mendukung ide ini adalah dengan mengembangkan aplikasi komputer yang dapat mengukur tubuh pengguna dan kemudian melihat gambaran citra pakaian yang dipilih jika dikenakan ke tubuh penggunanya. Aplikasi ini bisa disebut juga sebagai Virtual Fitting Room (VFR) [5]. Aplikasi VFR bisa dibuat dengan menggunakan berbagai metode dan pendekatan. Salah satu contoh pendekatan yang dilakukan adalah dengan menggunakan data depth data dari kamera yang memiliki depth sensor, misalnya Kinect. Gültepe \& Güdükbay (2014) mengajukan sebuah metode baru yang menggunakan depth sensor agar proses pengepasan (fitting) menjadi lebih realistik. Dalam penelitian tersebut, untuk mengatasi keakuratan depth data yang dihasilkan oleh depth sensor dikembangkan metode yang diberi nama Body Measurement. Metode ini menghasilkan proses yang cukup efisien dan tingkat akurasi pengepasan (fitting) yang semakin realistik. Secara umum, saat ini sistem pengepasan pakaian virtual VFR hanya memiliki fitur pengepasan pakaian saja [3] dan tidak memiliki fitur untuk menentukan ukuran pakaian yang sesuai dengan tubuh pengguna. Oleh karena itu, kami mengembangkan fitur untuk menentukan klasifikasi ukuran pakaian yang sesuai sehingga pengguna dapat menentukan ukuran pakaian yang sesuai dengan mudah.

Salah satu cara yang dapat digunakan untuk menentukan klasifikasi ukuran pakaian adalah menggunakan fuzzy logic. Fuzzy logic digunakan dalam penelitian ini karena pengukuran panjang bagian tubuh manusia dengan menggunakan kamera memiliki nilai keakuratan yang bersifat tidak absolut. Fuzzy logic merupakan pengembangan dari logika tradisional yang hanya menggunakan dua nilai kebenaran yaitu 0 dan 1 saja. Dalam fuzzy logic, nilai kebenaran bersifat multi-value dan bersifat kontinu antara 0 sampai dengan 1 [6]. Oleh karena itu, fuzzy logic cocok digunakan untuk menentukan klasifikasi di mana fitur yang terlibat tidak terlalu akurat nilainya.

Penelitian ini menggunakan metode body measurement untuk melakukan pengukuran pada tubuh pengguna menggunakan sensor Kinect dan kemudian menggunakan fuzzy logic untuk menentukan klasifikasi ukuran pakaian yang sesuai dengan tubuh pengguna. Aplikasi yang dikembangkan juga akan menggabungkan citra gambar pakaian secara virtual dengan citra gambar pengguna.Untuk menentukan ukuran pakaian yang sesuai dengan tubuh pengguna dibutuhkan pengukuran pada beberapa bagian tubuh manusia. Bagian tubuh manusia yang perlu diukur adalah lebar bahu (shoulder width), lebar dada (chest width), lebar pinggul (hip width), dan tinggi bagian atas tubuh manusia (upper body height). Apabila pengukuran beberapa bagian tubuh manusia tersebut dilakukan dengan sensor kamera, terdapat beberapa keterbatasan yang perlu diperhatikan. Keterbatasan yang ada adalah keterbatasan sensor kamera dalam mendeteksi ketebalan tubuh manusia dan sensor kamera yang hanya dapat menghasilkan citra gambar dalam bentuk dua dimensi. Hal ini tidak sesuai dengan nilai panjang bagian-bagian tubuh manusia yang sangat dipengaruhi oleh tingkat ketebalan tubuh manusia. Oleh karena itu, dalam penelitian ini perlu dilakukan uji korelasi antara hasil pengukuran yang didapat dari sensor kamera dengan hasil pengukuran dengan alat ukur manual.

\section{METODE PENELITIAN}

\section{Kinect}

Pada mulanya Kinect adalah alat pendeteksi gerakan dan suara untuk digunakan pada konsol permainan Xbox 360 dan Xbox One yang diproduksi oleh Microsoft. Pada tanggal 16 Juni 2011, Microsoft merilis Kinect Software Development Kit (Kinect SDK) yang dapat digunakan oleh para pengembang piranti lunak untuk memgembangkan aplikasi yang menggunakan Kinect. Sejak saat itu, Kinect banyak digunakan dalam penelitian computer vision. Kinect versi 1 (lihat Gambar 1) memiliki beberapa fitur utama yang meliputi: 
- Raw sensor stream yang dapat digunakan untuk mengakses informasi dari depth sensor, color camera sensor, dan microphone array.

- Skeletal tracking yang dapat digunakan untuk mendeteksi skeleton dari pengguna yang berada dalam jangkauan jarak pandang Kinect.

- Advanced audio capabilities yang memiliki beberapa kegunaan utama seperti effective noise suppression, acoustic echo cancellation, beamforming and source locatization.

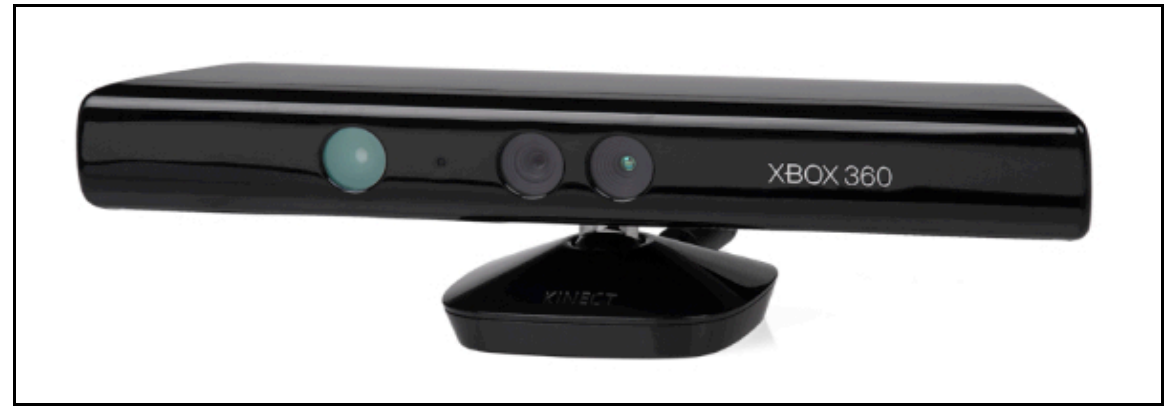

Gambar 1. Kinect

Kinect memiliki batasan-batasan penggunaan tertentu [4] agar penggunaan sensor kamera yang ada padanya dapat bekerja secara optimum. Batasan-batasan tersebut adalah:

1. Sudut pandang horizontal sebesar 57 derajat.

2. Sudut pandang vertikal sebesar 43 derajat.

3. Berada pada suhu ruangan 50 sampai dengan 350 Celcius.

4. Jarak pengguna yang berada pada 1.2 sampai dengan 4 meter untuk standard mode $(0.4$ sampai dengan 3 meter untuk near mode).

5. Jangkauan depth yang dihasilkan berada pada jangkauan $400 \mathrm{~mm}$ untuk near mode sampai $8000 \mathrm{~mm}$ untuk standard mode (lihat Gambar 2)

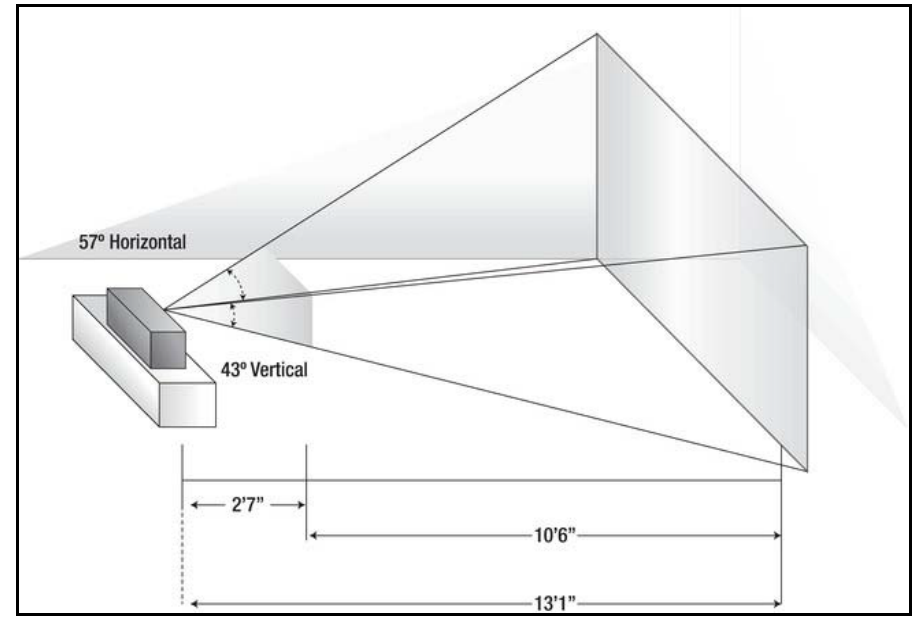

Gambar 2 Jangkauan jarak pandang Kinect

Dalam penelitian ini, sensor Kinect digunakan untuk mendeteksi nilai depth dengan cukup akurat dan juga untuk mendeteksi informasi joint location dari skeleton pengguna. Resolusi depth stream terbesar yang dapat dihasilkan oleh sensor Kinect adalah $640 \times 480$ piksel. Resolusi ini yang digunakan dalam penelitian yang dilakukan.

\subsection{Kinect Depth Data Measurement}

Menurut literatur [9], posisi koordinat X dan $\mathrm{Y}$ dari masing-masing depth pixel yang dihasilkan tidak berhubungan dengan pengukuran lebar dan tinggi dari sebuah objek yang 
sebenarnya. Namun, pengukuran lebar dan tinggi dari sebuah objek berdasarkan depth pixel yang dihasilkan sangat memungkinkan untuk dilakukan. Pengetahuan yang dapat digunakan untuk melakukan pengukuran sebuah objek berdasarkan depth pixel adalah:

1. Jangkauan pandangan kamera Kinect sebesar $57^{\circ}$ horizontal dan $43^{\circ}$ vertikal.

2. Jarak depth value.

3. Perhitungan trigonometri

Gambar berikut akan memberikan ilustrasi cara pengukuran objek berdasarkan depth pixel dengan menggunakan pengetahuan di atas:

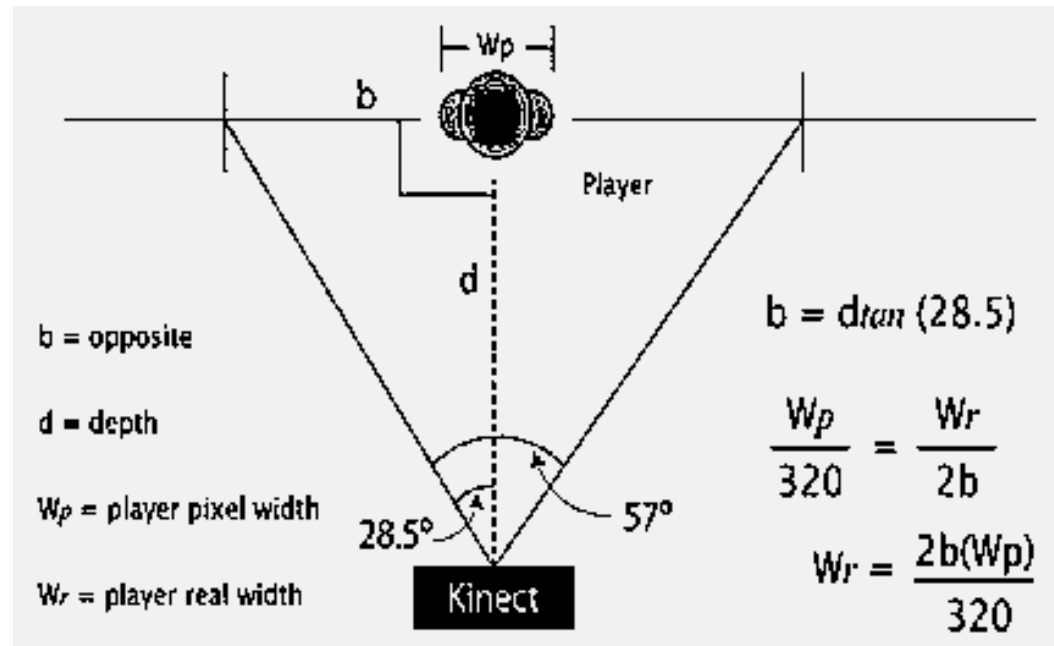

Gambar 3. Ilustrasi pengukuran lebar dan tinggi menggunakan depth pixel [9]

Dimana keterangan beberapa variabel pada Gambar 3 adalah:

- d adalah jarak depth value setiap pixel.

- $\mathrm{W}_{\mathrm{p}}$ adalah lebar objek yang diukur dalam satuan pixel.

- $\mathrm{W}_{\mathrm{r}}$ adalah lebar objek yang sesungguhnya dalam satuan meter atau centimeter.

- W adalah lebar dari resolusi depth stream yang dihasilkan oleh Kinect sensor (biasanya bernilai 640 atau 320 ).

Sebagai contoh, diketahui jarak depth value (d) berdasarkan sensor Kinect adalah 1500 $\mathrm{mm}$, lebar objek dalam pixel $\left(\mathrm{W}_{\mathrm{p}}\right)$ adalah 90 pixel, lebar resolusi depth stream $(\mathrm{W})$ adalah 640 pixel. Maka lebar objek sesungguhnya $\left(\mathrm{W}_{\mathrm{r}}\right)$ berdasarkan pengukuran didapat berdasarkan perhitungan berikut:

$$
\begin{aligned}
& b=d \times \tan (28.5)=1500 \mathrm{~mm} \times 0.543=814.434 \\
& W r=\frac{2 b \times W p}{640}=\frac{2 \times 814.434 \times 90}{640}=229.059 \mathrm{~mm}
\end{aligned}
$$

Perhitungan tinggi objek berdasarkan depth pixel menggunakan standar yang sama, namun parameter yang digunakan adalah tinggi objek dalam satuan pixel $(\mathrm{H})$, tinggi resolusi depth stream $(\mathrm{H})$ yang dihasilkan oleh Kinect sensor, dan besar sudut pandang dari Kinect sensor sebesar $43^{0}$ vertikal. 


\section{Pengukuran Bagian Tubuh Manusia}

\subsection{Pengukuran Langsung}

Pengukuran langsung pada bagian tubuh dilakukan dengan alat ukur panjang secara manual. Pengukuran dilakukan pada bagian tubuh lebar bahu (shoulder width), lingkar dada (chest width), lingkar pinggul (hip width), dan panjang tubuh bagian atas (upper body height).Pengukuran pada lebar bahu (shoulder width) dilakukan dengan mengukur panjang antara 2 titik perpanjangan ketiak pada bahu secara vertikal. Gambar 4 berikut ini menunjukkan pengukuran pada lebar bahu (shoulder width).

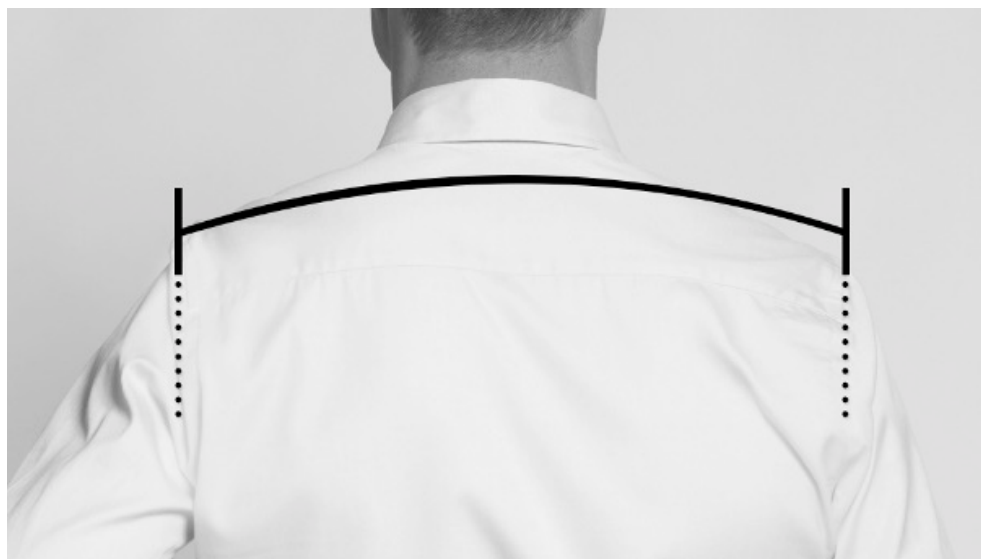

Gambar 4. Pengukuran pada lebar bahu (shoulder width) [8]

Pengukuran pada lingkar dada (chest width) dilakukan dengan melingkarkan alat ukur panjang pada bagian dada di titik-titik terluar pada dada. Gambar 5 berikut ini menunjukkan pengukuran pada lingkar dada.

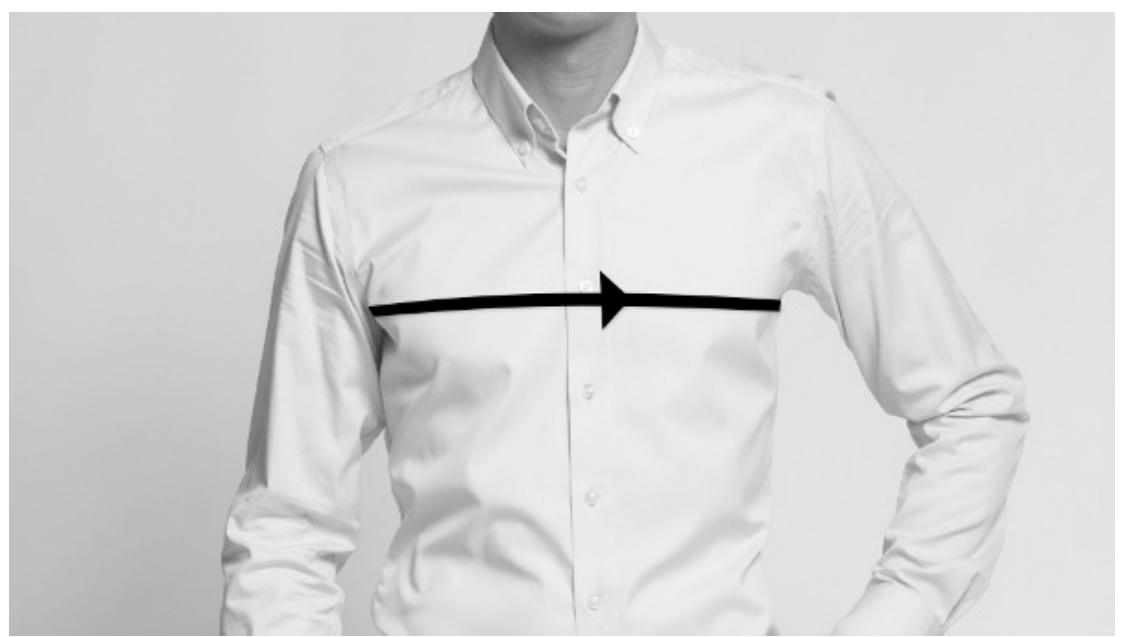

Gambar 5. Pengukuran pada lingkar dada (chest width) [8]

Pengukuran pada lingkar pinggul dilakukan dengan melingkarkan alat ukur panjang pada bagian pinggul di titik-titik terluar pada pinggul. Gambar 6 berikut ini menunjukkan pengukuran pada lingkar pinggul. 


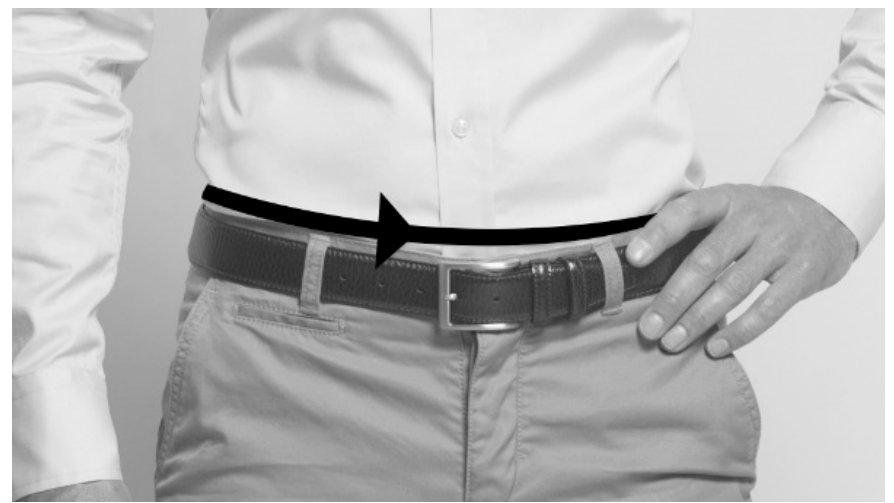

Gambar 6 Pengukuran pada lingkar pinggul (hip width) [8]

Pengukuran pada panjang tinggi bagian atas tubuh pengguna dilakukan dengan mengukur panjang antara bahu dan pinggul. Gambar 7 berikut ini menunjukkan pengukuran pada tinggi tubuh bagian atas (upper body height).



Gambar 7. Gambar pengukuran tubuh bagian atas (Upper Body Height) [8]

Dalam penelitian ini dilakukan pengukuran langsung dengan alat ukur panjang sebanyak 1 kali untuk 11 orang sukarelawan. Hasil pengukuran terdapat dalam Tabel 1 di bawah ini:

Tabel 1 Hasil Pengukuran Langsung Bagian Tubuh Manusia

\begin{tabular}{ccccc}
\hline No. & $\begin{array}{c}\text { Shoulder } \\
\text { Width }\end{array}$ & $\begin{array}{c}\text { Chest } \\
\text { Width }\end{array}$ & $\begin{array}{c}\text { Hip } \\
\text { Width }\end{array}$ & $\begin{array}{c}\text { Upper } \\
\text { Body } \\
\text { Height }\end{array}$ \\
\hline $\mathbf{1}$ & 42.5 & 45 & 47 & 48 \\
$\mathbf{2}$ & 39 & 40 & 44 & 43 \\
$\mathbf{3}$ & 42 & 45 & 49 & 47 \\
$\mathbf{4}$ & 44 & 47 & 49 & 48 \\
$\mathbf{5}$ & 43 & 47 & 44 & 48 \\
$\mathbf{6}$ & 45 & 50 & 48 & 49 \\
$\mathbf{7}$ & 46 & 49 & 48 & 50 \\
$\mathbf{8}$ & 49 & 55 & 50 & 55 \\
$\mathbf{9}$ & 48 & 55 & 50 & 54 \\
$\mathbf{1 0}$ & 51 & 58 & 52 & 59 \\
$\mathbf{1 1}$ & 51 & 58 & 50 & 60 \\
\hline
\end{tabular}


Hasil dari pengukuran langsung ini akan menjadi acuan bagi pengukuran panjang anggota tubuh secara tidak langsung dengan menggunakan sensor Kinect.

\subsection{Pengukuran Tidak Langsung}

Pengukuran tidak langsung dilakukan dengan menggunakan sensor Kinect berdasarkan metode body measurement. Pengukuran dilakukan untuk panjang lebar bahu (shoulder width), lebar dada (chest width), lebar pinggul (hip width), dan panjang tubuh bagian atas (upper body height). Pengukuran pada keempat bagian tubuh tersebut dihitung berdasarkan panduan pada Gambar 8 berikut ini.

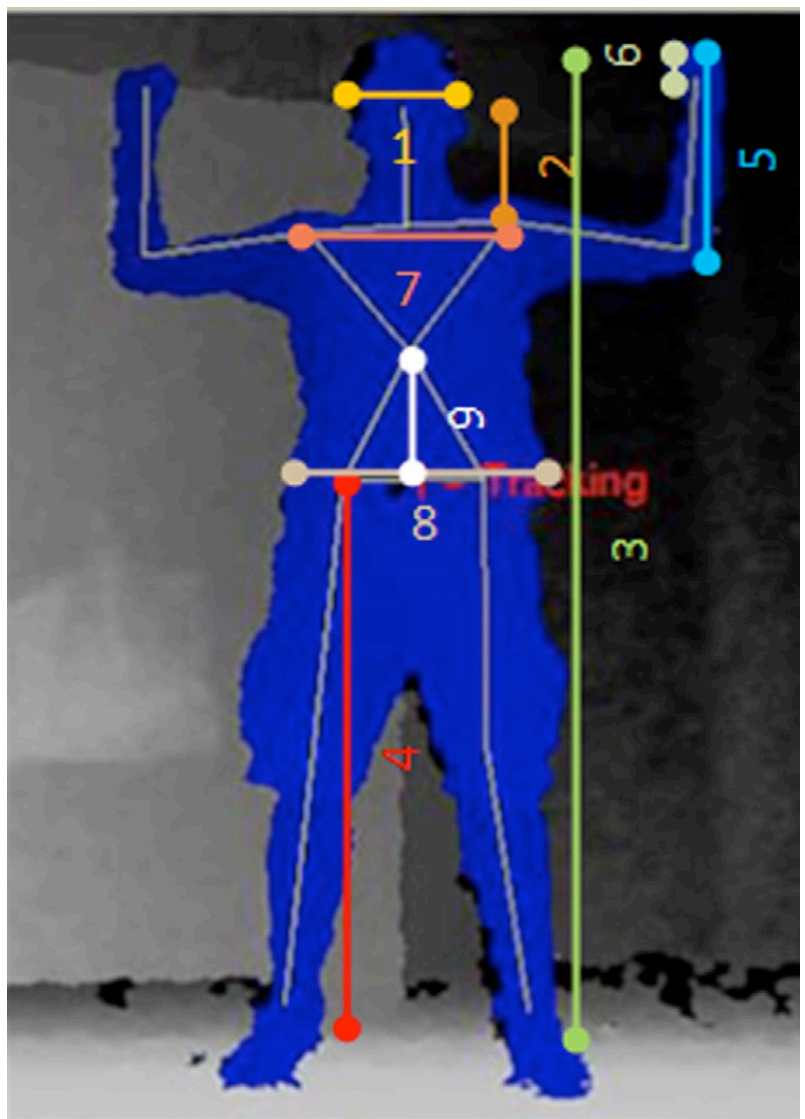

Gambar 8. Panduan pengukuran panjang bagian tubuh dengan Kinect [2]

Pengukuran pada lebar bahu (shoulder width) dilakukan berdasarkan panduan pada poin nomor 7 pada Gambar 8. Lebar bahu didapat berdasarkan titik skeletonShoulderCenter pada tubuh yang dideteksi oleh Kinect. Berdasarkan titik skeleton ShoulderCenter ini, ditarik garis horizontal pada tubuh pengguna dan akan dihitung jumlah pixel sepanjang garis horizontal tersebut berdasarkan metode Kinect Depth Data Measurement. Sedangkan pengukuran pada lebar pinggul (hip width) dilakukan berdasarkan panduan pada poin nomor 8 pada Gambar 8 . Lebar pinggul didapat berdasarkan titik skeletonHipCenter pada tubuh yang dideteksi oleh Kinect. Berdasarkan titik skeleton HipCenter, ditarik garis horizontal pada tubuh pengguna dan akan dihitung jumlah pixel sepanjang garis horizontal tersebut. Selanjutnya pengukuran pada lebar dada (chest width) dilakukan berdasarkan titik skeletonShoulderLeft dan ShoulderRight pada tubuh yang dideteksi oleh sensor Kinect. Nilai panjang lebar dada (chest width) dihitung berdasarkan jarak antara kedua titik tersebut dengan menggunakan Euclidean Distance. Terakhir untuk mengukur panjang tubuh bagian atas (upper body height) digunakan titik skeletonShoulderCenter dan HipCenter. Nilai tinggi tubuh bagian atas inidihitung berdasarkan jarak antara kedua titik tersebut dengan menggunakan Euclidean Distance. 
Pengukuran langsung dilakukan dengan menggunakan sensor kamera Kinect sebanyak 150 kali untuk 11 orang sukarelawan. Berdasarkan pengamatan, hasil pengukuran tidak langsung ini memiliki inkonsistensi data secara statistik. Hal ini disebabkan oleh hasil pengukuranyang tidak akurat pada saat awal pengukurandan juga dikarenakan pergerakan bagian tubuh yang terlalu cepat. Untuk mengantisipasi pergerakan badan yang cepat dapat dilakukan pose tracking seperti pada penelitian [10]. Uji Modified Thompson Tau [1] digunakan untuk menghilangkan data yang tidak konsisten (outlier) pada keseluruhan data yang ada. Uji Modified Thompson Tau dilakukan terhadap setiap bagian tubuh pada setiap sukarelawan sehingga diperoleh data yang valid kemudian dihitung nilai rata-rata pada masing-masing bagian tubuh untuk setiap sukarelawan. Berikut ini dalam Tabel 2 disajikan nilai rata-rata dari hasil pengukuran setelah data outlier dihilangkan.

Tabel 2 Nilai rata-rata hasil pengukuran tidak langsung setiap sukarelawan

\begin{tabular}{ccccc}
\hline No. & Shoulder Width & Chest Width & Hip Width & Upper Body Height \\
\hline $\mathbf{1}$ & 36.41035211 & 29.61085106 & 30.08605839 & 46.37327912 \\
\hline $\mathbf{2}$ & 35.45100719 & 26.53453333 & 29.13108108 & 41.99120167 \\
$\mathbf{3}$ & 35.49780822 & 28.66692308 & 30.19317568 & 43.16149537 \\
\hline $\mathbf{4}$ & 37.33150685 & 28.0165035 & 31.93662069 & 45.77768283 \\
\hline $\mathbf{5}$ & 37.40380952 & 29.76622222 & 29.35666667 & 46.01710367 \\
\hline $\mathbf{6}$ & 38.31166667 & 30.52978723 & 31.8988 & 47.31301219 \\
\hline $\mathbf{7}$ & 39.32034483 & 30.34340278 & 29.98993103 & 44.03531316 \\
\hline $\mathbf{8}$ & 40.26426573 & 32.03535211 & 31.76683824 & 42.94579414 \\
\hline $\mathbf{9}$ & 40.88108844 & 28.50520548 & 31.28785235 & 43.48202894 \\
\hline $\mathbf{1 0}$ & 39.98452703 & 32.24143836 & 33.21687075 & 45.6154326 \\
\hline $\mathbf{1 1}$ & 40.63829787 & 32.42181208 & 32.28006944 & 48.35909668 \\
\hline
\end{tabular}

\subsection{Uji Korelasi Hasil Pengukuran Tidak Langsung dan Langsung}

Pengukuran tidak langsung yang dilakukan dengan menggunakan sensor Kinect memiliki keterbatasan dalam mengukur ketebalan tubuh pengguna. Oleh karena itu, hasil pengukuran yang didapatkan bersifat garis lurus untuk masing-masing pengukuran panjang bagian tubuh Hal ini tidak sesuai dengan nilai panjang bagian-bagian tubuh manusia yang sangat dipengaruhi oleh tingkat ketebalan tubuh manusia. Uji korelasi dilakukan untuk menguji korelasi linear hasil pengukuran tidak langsung dengan hasil pengukuran langsung. Jika terdapat korelasi yang kuat maka hasil pengukuran tidak langsung dapat digunakan sebagai estimator bagi hasil pengukuran langsung.

Uji korelasi antar hasil pengukuran tidak langsung dan hasil pengukuran langsung akan dilakukan untuk setiap bagian tubuh manusia. Jika uji korelasi untuk setiap bagian tubuh manusia menghasilkan nilai $P$-value yang lebih kecil dari tingkat signifikansi $\alpha=1 \%$, maka hasil pengukuran tidak langsung dengan sensor Kinect memiliki korelasi terhadap pengukuran langsung pada bagian tubuh yang bersangkutan. Selanjutnya jika hasil pengukuran tidak langsung memiliki korelasi terhadap pengukuran langsung, maka pengukuran menggunakan sensor Kinect untuk bagian tubuh tersebut dapat digunakan sebagai salah satu faktor penentu dalam klasifikasi ukuran pakaian yang sesuai. Hasil uji korelasi antara hasil pengukuran tidak langsung dan pengukuran langsung ditunjukkan pada tabel sebagai berikut: 
Computatio: Journal of Computer Science and Information Systems

Volume 1 Tahun 2017

Tabel 3 Tabel analisis korelasi pengukuran langsung dan tidak langsung

\begin{tabular}{|c|c|c|c|}
\hline \multirow{2}{*}{ Bagian Tubuh } & \multicolumn{2}{|c|}{ P-value } & \multirow{2}{*}{ Hasil Analisis } \\
\hline & Intercept & $x$-value & \\
\hline Shoulder Width & 0.02826 & $2.81 \mathrm{E}-05$ & Memiliki korelasi \\
\hline Chest Width & 0.199507 & 0.002682 & Memiliki korelasi \\
\hline Hip Width & 0.835941 & 0.000603 & Memiliki korelasi \\
\hline Upper Body Height & 0.878876 & 0.248109 & Tidak memiliki korelasi \\
\hline
\end{tabular}

Oleh karena itu, berdasarkan analisis hasil uji korelasi di atas, bagian tubuh yang dapat dijadikan sebagai salah satu faktor penentu dalam penentuan klasifikasi ukuran pakaian adalah lebar bahu (shoulder width), lebar dada (chest width), dan lebar pinggul (hip width). Sedangkan hasil uji korelasi juga menunjukkan bahwa pengukuran tidak langsung pada tinggi bagian atas tubuh manusia (upper body height) tidak signifikan. Hasil ini sesuai dengan penelitian yang dilakukan oleh [7] yang menyatakan pengukuran tinggi tubuh manusia dengan sensor Kinect berdasarkan lokasi joint center tidak memenuhi akurasi dari standar klinis.

\section{Klasifikasi Ukuran Pakaian}

Berdasarkan hasil uji korelasi pada Tabel 3, terdapat tiga bagian tubuh (shoulder width, chest width, dan hip width) yang dapat digunakan sebagai faktor penentu dalam menentukan klasifikasi ukuran pakaian yang sesuai. Tiga bagian tubuh tersebut akan dijadikan variabel input untuk metodefuzzy yang akan digunakan. Proses fuzzify dilakukan untuk setiap variabel input sehingga menghasilkan himpunan fuzzy yang terdiri dari tiga bagian yaitu Low, Medium, dan High. Fungsi keanggotaan (membership function) untuk bagian Low dan High akan digunakan kurva berbentuk trapesium, sedangkan untuk bagian Medium, akan digunakan kurva berbentuk segitiga. Penentuan rentang nilai untuk sampel dilakukan berdasarkan sampel yang sudah dibagi menjadi tiga kelompok (Small, Medium, dan Large). Rentang nilai untuk bagian Low, Medium, dan High ditentukan berdasarkan nilai rata-rata $\mu$ dan variansi $\sigma$ dari sampel $(\mu \pm \sigma)$, terkecuali untuk Shoulder Width digunakan rentang nilai sebesar $(\mu \pm 2 \sigma)$ karena nilai variansinya yang kecil sehingga rentang nilai perlu diperpanjang agar dapat menjangkau keseluruhan hasil pengukuran yang ada.

Tabel 4, 5, dan 6 berikut ini menunjukan rentang nilai (Low, Medium, dan High) untuk fungsi keanggotaan pada bagian tubuh shoulder width, chest width, dan hip width.

Tabel 4 Tabel Rentang Nilai Shoulder Width

\begin{tabular}{lccc}
\hline \multicolumn{1}{c}{ Shoulder Width } & Low & Medium & High \\
\hline Rata-rata & 35.78639 & 38.09183 & 40.44204 \\
Variansi & 0.540874 & 0.932566 & 0.396738 \\
$\boldsymbol{\mu - 2} \boldsymbol{~}$ & 34.70464 & 36.2267 & 39.64857 \\
$\boldsymbol{\mu + 2 \boldsymbol { \sigma }}$ & 36.86814 & 39.95696 & 41.23552 \\
\hline
\end{tabular}

Tabel 5 Tabel Rentang Nilai Chest Width

\begin{tabular}{lccc}
\multicolumn{1}{c}{ Chest Width } & Low & Medium & High \\
\hline Rata-rata & 28.27076916 & 29.66397893 & 31.30095201 \\
Variansi & 1.575955628 & 1.145406737 & 1.87050653 \\
$\boldsymbol{\mu}-\boldsymbol{\sigma}$ & 26.69481 & 28.51857 & 29.43045 \\
$\boldsymbol{\mu}+\boldsymbol{\sigma}$ & 29.84672 & 30.80939 & 33.17146 \\
\hline
\end{tabular}


Computatio: Journal of Computer Science and Information Systems

Volume 1 Tahun 2017

Tabel 6 .Tabel Rentang Nilai Hip Width

\begin{tabular}{lccc}
\hline \multicolumn{1}{r}{ Hip Width } & Low & Medium & High \\
\hline Rata-rata & 29.80343838 & 30.7955046 & 32.13790769 \\
Variansi & 0.584736509 & 1.321439876 & 0.825562004 \\
$\boldsymbol{\mu}-\boldsymbol{\sigma}$ & 29.2187 & 29.47406 & 31.31235 \\
$\boldsymbol{\mu}+\boldsymbol{\sigma}$ & 30.38817 & 32.11694 & 32.96347 \\
\hline
\end{tabular}

Gambar 9 berikut ini menunjukkan contoh kurva fungsi keanggotaan yang berbentuk trapesium untuk Shoulder Width.

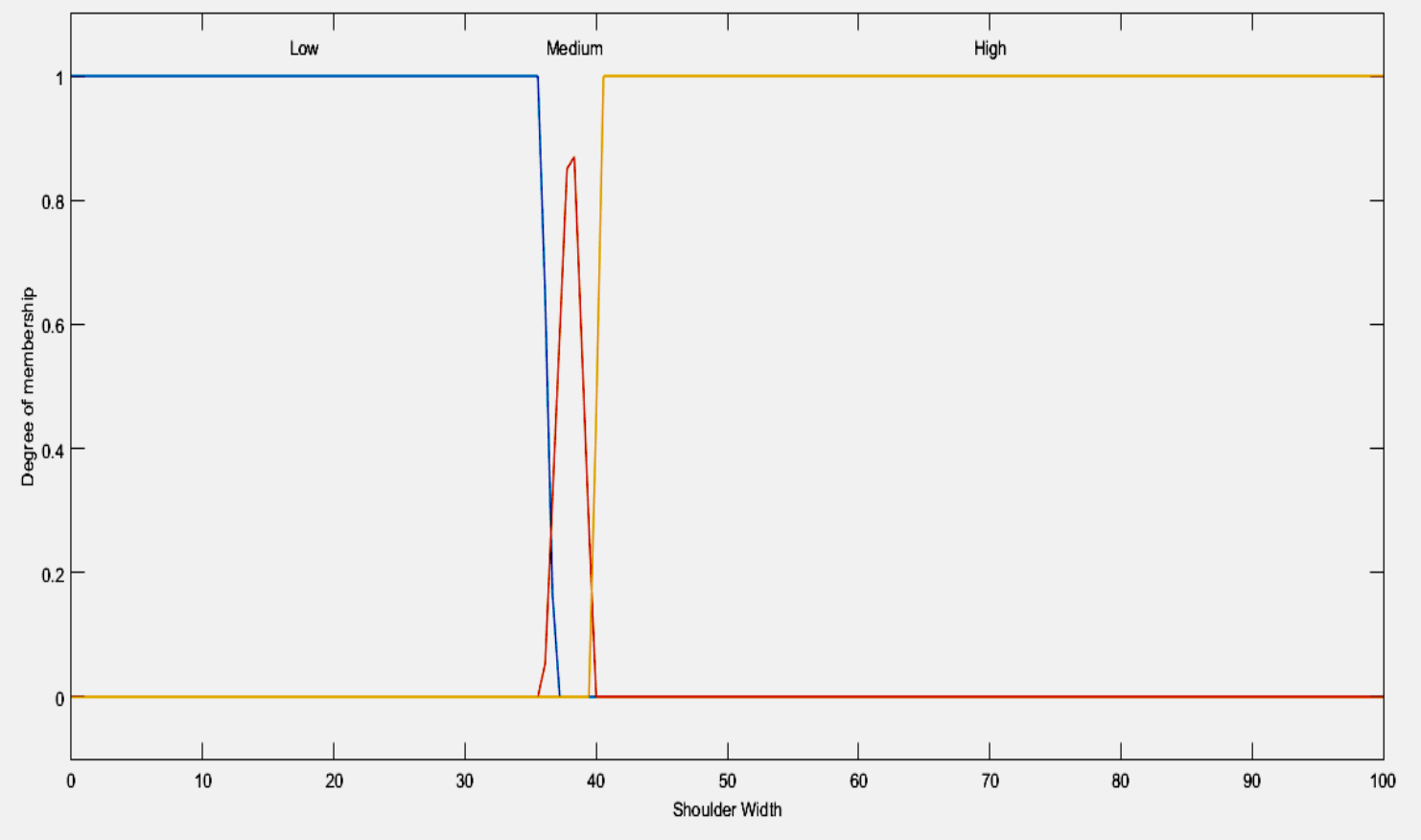

Gambar 9. Fungsi Keanggotaan untuk Shoulder Width

\subsection{Fuzzy Rule}

Tahapan terakhir dalam pembangunan metode fuzzy [6] adalah penentuan fuzzy rule sebagai aturan dalam penentuan ukuran pakaian yang sesuai. Dalam pembuatannya, terdapat beberapa pertimbangan mengenai bagian tubuh yang menjadi prioritas dalam penentuan klasifikasi ukuran pakaian. Pertimbangan mengenai prioritas ini dilakukan karena adanya perbedaan nilai $P$-Value pada masing-masing bagian tubuh. Nilai $P$-Value yang semakin kecil menandakan bahwa estimasi bagian tubuh tersebut sangat berkorelasi dengan nilai pengukuran langsung. Oleh karena itu, pertimbangan mengenai bagian tubuh yang menjadi prioritas ditentukan berdasarkan nilai $P$-Value yang ada pada Tabel 7. Semakin rendah nilai P-Value, maka prioritas yang diberikan untuk bagian tubuh yang bersangkutan semakin tinggi. Urutan prioritas nilai $P$-Value pada bagian tubuh ditunjukkan pada Tabel 7 berikut:

Tabel 6 Tabel prioritas bagian tubuh

\begin{tabular}{lccc}
\hline \multirow{2}{*}{ Bagian Tubuh } & \multicolumn{2}{c}{ P-Value } & \multirow{2}{*}{ Prioritas } \\
\cline { 2 - 3 } & Intercept & X-Value & \\
\hline Shoulder Width & 0.02826 & $2.81 \times 10^{-5}$ & 1 \\
Chest Width & 0.199507 & 0.002682 & 3 \\
Hip Width & 0.835941 & 0.000603 & 2 \\
\hline
\end{tabular}


Dalam pembuatannya, fuzzy rule yang dibangun menggunakan prioritas bagian tubuh dan juga pengalaman empiris sebagai acuan. Rule berdasar prioritas yang digunakan dalam penentuan fuzzy rule adalah sebagai berikut:

1. Jika Shoulder Width berukuran High, maka hasil klasifikasi ukuran pakaian berukuran Large karena adanya pertimbangan mengenai pakaian yang tidak dapat nyaman digunakan jika hasil klasifikasi ukuran lebih kecil dari ukuran Large.

2. Jika Shoulder Width berukuran Medium dan Hip Width berukuran High, maka ukuran pakaian berukuran Large karena adanya pertimbangan mengenai ukuran pakaian yang menyesuaikan ukuran pinggul sebagai prioritas 2 dalam penentuan ukuran pakaian.

3. Jika Shoulder Width berukuran Low dan Hip Width berukuran Medium atau High, maka ukuran pakaian akan mengikuti ukuran Hip Width (Medium atau Large) karena adanya pertimbangan mengenai ukuran pakaian yang menyesuaikan ukuran pinggul sebagai prioritas 2 dalam penentuan ukuran pakaian.

Berdasarkan pengalaman empiris, terdapat beberapa penyesuaian dari fuzzy rule yang dibangun. Penyesuaian rule tersebut antara lain:

1. Jika Shoulder Width berukuran Medium dan Hip Width berukuran High, maka ukuran pakaian juga mempertimbangkan ukuran Chest Width. Jika Chest Width bernilai Low, maka ukuran pakaian akan menjadi Medium. Jika Chest Width bernilai Medium atau High, maka ukuran pakaian akan menjadi Large.

2. Jika Shoulder Width berukuran Low dan Hip Width berukuran Medium atau High, maka ukuran pakaian juga mempertimbangkan ukuran Chest Width. Jika Chest Width bernilai Low, maka ukuran pakaian akan menjadi Small. Jika Chest Width bernilai Medium atau High, maka ukuran pakaian akan menjadi Medium atau High.

Berikut ini adalah keseluruhan fuzzy rule yang digunakan untuk penentuan ukuran pakaian yang sesuai:

Tabel 7 Tabel Fuzzy Rule

\begin{tabular}{|c|c|c|c|c|}
\hline No. & Shoulder Width & Chest Width & Hip Width & Result \\
\hline 1. & Low & Low & Low & Small \\
\hline 2. & Low & Low & Medium & Small \\
\hline 3. & Low & Low & High & Small \\
\hline 4. & Low & Medium & Low & Small \\
\hline 5. & Low & Medium & Medium & Medium \\
\hline 6. & Low & Medium & High & Medium \\
\hline 7. & Low & High & Low & Small \\
\hline 8. & Low & High & Medium & Medium \\
\hline 9. & Low & High & High & Large \\
\hline 10. & Medium & Low & Low & Medium \\
\hline 11. & Medium & Low & Medium & Medium \\
\hline 12. & Medium & Low & High & Medium \\
\hline 13. & Medium & Medium & Low & Medium \\
\hline 14. & Medium & Medium & Medium & Medium \\
\hline 15. & Medium & Medium & High & Large \\
\hline 16. & Medium & High & Low & Medium \\
\hline 17. & Medium & High & Medium & Medium \\
\hline 18. & Medium & High & High & Large \\
\hline 19. & High & Low & Low & Large \\
\hline 20. & High & Low & Medium & Large \\
\hline 21. & High & Low & High & Large \\
\hline 22. & High & Medium & Low & Large \\
\hline 23. & High & Medium & Medium & Large \\
\hline 24. & High & Medium & High & Large \\
\hline 25. & High & High & Low & Large \\
\hline
\end{tabular}


Computatio: Journal of Computer Science and Information Systems Volume 1 Tahun 2017

\begin{tabular}{lllcl}
\hline 26. & High & High & Medium & Large \\
27. & High & High & High & Large \\
\hline
\end{tabular}

\section{PEMBAHASAN}

Aplikasi Virtual Fitting Room (VFR) yang dibangun untuk menentukan klasifikasi ukuran pakaian, dan sekaligus untuk melihat pengepasan (fitting) pakaian pada tubuh pengguna. Tampilan aplikasi VPR ini terlihat seperti pada Gambar 10 berikut ini.

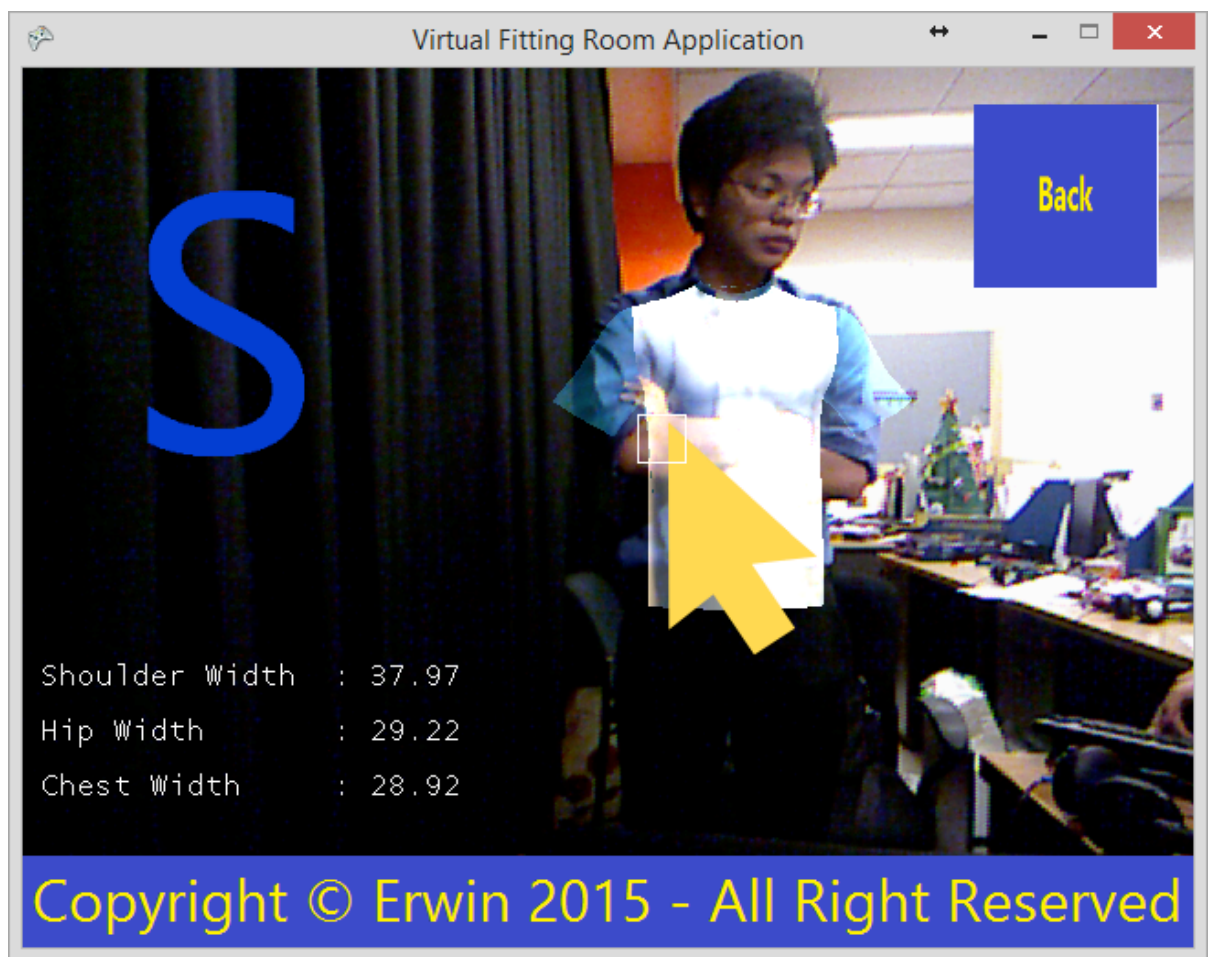

Gambar 10. Tampilan layar aplikasi Virtual Fitting Room

Evaluasi terhadap unjuk kerja aplikasi VFR ini dilakukan dengan membandingkan hasil klasifikasi ukuran pakaian pada aplikasi VPR dengan hasil pengukuran sebenarnya. Jumlah sukarelawan untuk melakukan evaluasi ini adalah 11 orang. Setiap sukarelawan sudah diukur secara langsung secara manual dan kemudian ditentukan ukuran pakaiannya. Prosedur untuk simulasi pengukuran tidak langsung ditentukan sebagai berikut:

1. Jarak antara sukarelawan dan Kinect Sensor berada di antara $120-150 \mathrm{~cm}$.

2. Simulasi dilakuan di ruang tertutup di mana tidak ada objek lain di samping dan di belakang sukarelawan.

3. Pengukuran hanya dilakukan untuk setiap orang satu per satu.

Pada pengukuran tidak langsung menggunakan sensor Kinect, para sukarelawan ini diambil datanya sebanyak 150 kali dalam jangka waktu 5 sampai 6 detik. Hasil dari pengukuran tidak langsung ini selanjutnya diuji konsistensinya dengan uji outlier Modified Thompson Tau. Hanya sekitar $82 \%$ dari hasil pengukuran langsung ini yang lolos uji outlier ini. Hal ini disebabkan oleh hasil pengukuran yang tidak akurat pada saat awal pengukurandan juga dikarenakan pergerakan bagian tubuh yang terlalu cepat. Sehingga total hasil pengukuran tidak langsung yang diklasifikasikan dengan metode fuzzy berjumlah 1358 data. 

berikut:

Hasil evaluasi untuk semua sukarelawan kemudian digabungkan dalam Tabel 9 sebagai

Tabel 8 Tabel Perbandingan Hasil Klasifikasi Ukuran Pakaian

\begin{tabular}{|c|c|c|c|c|c|}
\hline \multirow{2}{*}{\multicolumn{2}{|c|}{ Grand Total }} & \multicolumn{3}{|c|}{ Klasifikasi Ukuran Menggunakan Aplikasi } & \multirow{3}{*}{$\begin{array}{c}\begin{array}{c}\text { Akurasi } \\
(\%)\end{array} \\
94.99 \%\end{array}$} \\
\hline & & \multirow{2}{*}{$\frac{\text { Small }}{398}$} & \multirow{2}{*}{$\frac{\text { Medium }}{21}$} & \multirow{2}{*}{$\frac{\text { Large }}{0}$} & \\
\hline \multirow{3}{*}{$\begin{array}{c}\text { Ukuran } \\
\text { Sebenarnya }\end{array}$} & Small & & & & \\
\hline & Medium & 12 & 340 & 18 & $91.89 \%$ \\
\hline & Large & 0 & 22 & 547 & $96.13 \%$ \\
\hline \multicolumn{2}{|c|}{ Total } & 410 & 383 & 565 & $94.34 \%$ \\
\hline
\end{tabular}

Berdasarkan tabel perbandingan hasil klarifikasi di atas, data yang diperoleh akan dianalisis untuk mengetahui tingkat kesalahan menggunakan False Match Rate (FMR). FMR adalah persentase banyaknya terjadinya kejadian sistem salah mengidentifikasi suatu input yang tidak sesuai. Berdasarkan perhitungan FMR dapat diperoleh tingkat performa klasifikasi ukuran pakaian dari aplikasi yang dibangun. Tabel berikut menunjukkan hasil analisis untuk klasifikasi ukuran pakaian (Small, Medium, dan Large).

Tabel 9 Tabel Tingkat Akurasi Setiap Metrik untuk Ukuran Pakaian

\begin{tabular}{cc}
\hline Metric FMR & Tingkat Akurasi (\%) \\
\hline Small & $2.22 \%$ \\
Medium & $3.08 \%$ \\
Large & $2.78 \%$ \\
Rata-rata & $2.69 \%$ \\
\hline
\end{tabular}

Berdasarkan Tabel 10 di atas, dapat disimpulkan bahwa rata-rata FMR dalam proses klasifikasi ukuran pakaian berkisar antara 2.68\%. Tingkat FMR ini cukup rendah sehingga pendekatan klasifikasi dengan metode fuzzy layak untuk diterapkan pada kasus ini. Selain itu aplikasi yang dikembangkan dapat melakukan klasifikasi ukuran pakaian secara cepat dan tidak ditemukan adanya delay yang menghambat jalannya program. Hal ini berarti aplikasi VFR dapat melakukan klasifikasi ukuran pakaian (Small, Medium, dan Large) secara real-time dengan tingkat FMR yang cukup kecil.

\section{KESIMPULAN}

Aplikasi yang dikembangkan bangun berdasarkan metode body measurement dan Fuzzy Logic miliki kehandalan dalam waktu pendeteksian sehingga proses pengepasan dapat dilakukan secara real time. Aplikasi ini dapat melakukan klasifikasi ukuran pakaian tanpa ditemukan delay yang menghambat jalannya program.Berdasarkan eksperimen yang dilakukan, unjuk kerja aplikasi VFR termasuk baik karena dapat menentukan klasifikasi ukuran pakaian pengguna dengan tingkat FMR yang cukup kecil yaitu rata-rata sebesar $2.69 \%$ dengan menggunakan tiga faktor yaitu bagian tubuh lebar bahu (shoulder width), lingkar dada (chest width), lingkar pinggul (hip width). Sedangkan faktor tinggi bagian atas tubuh (upper body height) tidak berpengaruh terhadap penentuan klasifikasi ukuran pakaian berdasarkan hasil uji korelasi dengan pengukuran langsung secara manual. Hal ini diakibatkan pengukuran tinggi 
tubuh manusia dengan sensor Kinect berdasarkan lokasi joint center, sehingga penelitian selanjutnya perlu dilakukan perbaikan dalam metode perhitungan tinggi tubuh manusia ini dan juga antisipasi untuk pergerakan tubuh yang cepat.

\section{DAFTAR PUSTAKA}

[1] Cimbala, J. (2011). Outliers. (Penn State University) Diambil kembali dari http://www.mne.psu.edu/cimbala/me345/Lectures/Outliers.pdf

[2] Gültepe, U., \& Güdükbay, U. (2014). Real-time virtual fitting with body measurement and motion smoothing. Computers \& Graphics, 43, 31-43.

[3] Isikdogan, F., \& Kara, G. (2012). A Real Time Virtual Dressing Room Application using Kinect. BOGAZICI UNIVERSITY. Diambil kembali dari http://www.isikdogan.com/files/isikdogan_kinect.pdf

[4] Khoshelham, K. (2011). ACCURACY ANALYSIS OF KINECT DEPTH DATA. International Archives of the Photogrammetry, Remote Sensing and Spatial Information Sciences, XXXVIII5/W12, hal. 133-138. Calgary.

[5] Pachoulakis, I., \& Kapetanakis, K. (2012). Augmented Reality Platforms for Virtual Fitting Room. The International Journal of Multimedia \& Its Applications (IJMA), 4(4), 35-46.

[6] Ross, T. J. (2016). Fuzzy Logic with Engineering Applications (4 ed.). Wiley.

[7] Sinha, S., Bhowmick, B., Chakravarty, K., Sinha, A., \& Das, A. (2016). Accurate upper body rehabilitation system using kinect. Engineering in Medicine and Biology Society (EMBC), IEEE 38th Annual International Conference of the (hal. 4605-4609). IEEE.

[8] Store, T. (t.thn.). Men's body measurements. Diambil kembali dari https://www.tailorstore.com/mens-body-measurements.pdf

[9] Webb, J., \& Ashley, J. (2012). Beginning Kinect Programming with The Microsoft Kinect SDK. Apress.

[10] Ye, M., Wang, H., Deng, N., Yang, X., \& Yang, R. (2014). Real-Time Human Pose and Shape Estimation for Virtual Try-On Using a Single Commodity Depth Camera. IEEE Transactions on Visualization and Computer Graphics (TVCG). 